\begin{tabular}{|c|c|}
\hline Title & Development of Direct-Ethanol A nion-Conducting Solid A Ikaline Inorganic Fuel Cell \\
\hline Author(s) & Takeguchi, Tatsuy a; Takahashi, Hiroki; Y amanaka, Toshiro; Nakamura, A yaka; Ueda, W ataru \\
\hline Citation & $\begin{array}{l}\text { ECS Transactions, 33(1), 1847-1851 } \\
\text { https:/doi .org/10.1149/1.3484675 }\end{array}$ \\
\hline Issue Date & 2010 \\
\hline Doc URL & http:/hdl .handle.net/2115/48159 \\
\hline Rights & $\begin{array}{l}\text { (1) The Electrochemical Society, Inc. 2010. All rights reserved. Except as provided under U.S. copyright law, this work } \\
\text { may not be reproduced, resold, distributed, or modified without the express permission of The Electrochemical Society } \\
\text { (ECS). The archival version of this work was published in ECS Trans., 33(1), pp.1847-1851. }\end{array}$ \\
\hline Type & article \\
\hline File Information & ECSt33-1_1847-1851.pdf \\
\hline
\end{tabular}

Instructions for use 


\title{
Development of Direct-Ethanol Anion-Conducting Solid Alkaline Inorganic Fuel Cell
}

\author{
Tatsuya Takeguchi, Hiroki Takahashi, Toshiro Yamanaka, Ayaka Nakamura, \\ and Wataru Ueda \\ Catalysis Research Center, Hokkaido University, Sapporo 001-0021, Japan
}

Anion-conducting solid alkaline inorganic fuels cell was developed. This fuel cell could be operated at high temperature of $110^{\circ} \mathrm{C}$. $\mathrm{NaCO}_{2} \mathrm{O}_{4}$ showed $\mathrm{OH}^{-}$conduction and activity for oxygen reduction reaction. The $\mathrm{Fe}-\mathrm{Co}-\mathrm{Ni}$ alloy catalyst prepared in this experiment showed activity not only for hydrogen oxidation reaction but also for ethanol oxidation reaction. Completely precious metal-free fuel cell composed of $\mathrm{NaCo}_{2} \mathrm{O}_{4}$ and $\mathrm{Fe}-\mathrm{Co}-\mathrm{Ni}$ cell was made. The cell generated a high output power density of $64 \mathrm{~mW} / \mathrm{cm}^{2}$ directly from ethanol at current density of 160 $\mathrm{mA} / \mathrm{cm}^{2}$.

\section{Introduction}

In general, $\mathrm{H}_{2}$ is used as a fuel for fuel cells. However, storage of $\mathrm{H}_{2}$ is one of the serious problems for fuel cell system. Fuel cells with direct liquid feeds, such as alcohols, are desirable. Pt anode catalyst for Polymer electrolyte fuel cells (PEFCs) can activate both of $\mathrm{H}-\mathrm{H}$ and $\mathrm{C}-\mathrm{H}$ bond, but it cannot activate $\mathrm{C}-\mathrm{C}$ bond. PEFCs can directly use methanol, but they cannot use ethanol as fuels.

On the other hand, since C-C bond can be activated by transition metal catalyst at basic condition, ethanol can be used for direct alkaline fuel cells. It is well known that the rate of oxygen reduction reaction (ORR) $\left(2 \mathrm{H}_{2} \mathrm{O}+\mathrm{O}_{2}+4 \mathrm{e}^{-} \rightarrow 4 \mathrm{OH}^{-}\right)$in an AFC is much higher than ORR $\left(4 \mathrm{H}^{+}+\mathrm{O}_{2}+4 \mathrm{e}^{-} \rightarrow 4 \mathrm{H}_{2} \mathrm{O}\right)$ of a PEFC. Therefore, non-precious metals can be used as the cathode catalyst in an AFC instead of Pt. Since a KOH electrolyte solution is usually used for $\mathrm{AFC}$, it reacts easily with dissolved $\mathrm{CO}_{2}$ to form carbonate. When anion-exchange membrane is used, the maximum temperature is around $60^{\circ} \mathrm{C}(1-3)$. Fuel cells available over $100^{\circ} \mathrm{C}$ is strongly desired especially for vehicles without a huge size of radiator (4). If fuel cells could be operated in the high temperature over $110^{\circ} \mathrm{C}$, the wide spread use of fuel cell is expected.

In this study, to prevent formation of carbonate species, inorganic anion-exchange membrane composed of $\mathrm{NaCo}_{2} \mathrm{O}_{4}$ having layered structures (5) was used. Thermal resistance over $110^{\circ} \mathrm{C}$ was confirmed. Fe-Co-Ni alloy catalysts were prepared, and directethanol fuel cell was developed.

\section{Experimental section}

\section{$\underline{\text { Preparation of Electrolyte and Catalyst }}$}

$\mathrm{CH}_{3} \mathrm{COONa}$ and $\left(\mathrm{CH}_{3} \mathrm{COO}\right)_{2} \mathrm{Co} \bullet 4 \mathrm{H}_{2} \mathrm{O}$ were dissolved in water. This solution was dried at $80^{\circ} \mathrm{C}$ with stirring, and kept in an oven overnight at $80^{\circ} \mathrm{C}$. The dried powder wase

milled, and calcined at $750^{\circ} \mathrm{C}$ for $5 \mathrm{~h}$. The calcined sample was crushed and pelleted. The 
pellets were calcined at $790^{\circ} \mathrm{C}$ and crushed. The $\mathrm{NaCo}_{2} \mathrm{O}_{4}$ powder was obtained (1) and used to prepare a $\mathrm{NaCo}_{2} \mathrm{O}_{4}$ disk for a fuel cell device. The $\mathrm{NaCo}_{2} \mathrm{O}_{4}$ powder was pressed at $30 \mathrm{MPa}$ for $5 \mathrm{~min}$, and pelleted into a $20 \mathrm{~mm}$ diameter, $1 \mathrm{~mm}$ thick disk. The disks were calcined at $900{ }^{\circ} \mathrm{C}$ for $32 \mathrm{~h}$ to form the final $\mathrm{NaCo}_{2} \mathrm{O}_{4}$ disks, and one of the disks was crushed to form powders.

The $\mathrm{NaCO}_{2} \mathrm{O}_{4}$ powders were impregnated with an aqueous solution of $\mathrm{Pd}\left(\mathrm{NH}_{3}\right)_{2}\left(\mathrm{NO}_{2}\right)_{2}$. These were dried at $80^{\circ} \mathrm{C}$ and calcined at $600^{\circ} \mathrm{C}$ for $2 \mathrm{~h}$ to form $15 \mathrm{wt} \%$ $\mathrm{Pd} / \mathrm{NaCo}_{2} \mathrm{O}_{4} .10 \mathrm{mg}$ of $15 \mathrm{wt} \% \mathrm{Pd} / \mathrm{NaCo}_{2} \mathrm{O}_{4}$ was mixed with $4 \mu \mathrm{L}$ of ethylene glycol to form $\mathrm{Pd} / \mathrm{NaCo}_{2} \mathrm{O}_{4}$ paste. The anode of the remaining $\mathrm{NaCo}_{2} \mathrm{O}_{4}$ disk was painted with the $\mathrm{Pd} / \mathrm{NaCO}_{2} \mathrm{O}_{4}$ paste. The painted $\mathrm{NaCo}_{2} \mathrm{O}_{4}$ disk was calcined at $400^{\circ} \mathrm{C}$ to form $\mathrm{Pd} / \mathrm{NaCo}_{2} \mathrm{O}_{4} / \mathrm{NaCo}_{2} \mathrm{O}_{4}$ disk. The disk was reduced at $280^{\circ} \mathrm{C}$ in $\mathrm{H}_{2}$ humidified at room temperature. The area of the anode was $0.28 \mathrm{~cm}^{2}$ and the Pd loading was $2 \mathrm{mg} / \mathrm{cm}^{2}$.

$\mathrm{Fe}-\mathrm{Co}-\mathrm{Ni}$ catalyst (6): Vulcan powders were impregnated with a mixed aqueous solution of nitrate of $\mathrm{Fe}, \mathrm{Co}$, and $\mathrm{Ni}$, followed by drying and reduction. Fe-Co-Ni loading was $55 \mathrm{wt} \%$ with molar ratio of $\mathrm{Fe} / \mathrm{Co} / 10=1 / 1 / 1$. The anode of the $\mathrm{NaCoO}_{4}$ disk was painted with $\mathrm{Fe}-\mathrm{Co}-\mathrm{Ni} / \mathrm{C}$ past mixed with ethylene glycol. Fe-Co-Ni loading was 10 $\mathrm{mg} / \mathrm{cm}^{2}$.

\section{Cell Performance Test}

The $\mathrm{Pd} / \mathrm{NaCo}_{2} \mathrm{O}_{4} / \mathrm{NaCo}_{2} \mathrm{O}_{4}$ disk was placed between two sheets of platinum mesh current collectors at anode and carbon paper current collectors. Fuel-cell polarization curves were collected at the room temperature and $110^{\circ} \mathrm{C}$. The current densities were measured in $20 \mathrm{~mL}$ flow of dry $\mathrm{H}_{2}$ at the anode and in $20 \mathrm{~mL}$ flow of $\mathrm{H}_{2} \mathrm{O}$-saturated $\mathrm{O}_{2}$ at $75^{\circ} \mathrm{C}$ at the cathode.

Apparatus for direct-ethanol fuel cell is shown in Figure 1. Fe-Co-Ni/ $\mathrm{NaCo}_{2} \mathrm{O}_{4}$ disk was placed between two sheets of platinum mesh current collectors at anode and carbon paper current collectors. Fuel-cell polarization curves were collected at $80^{\circ} \mathrm{C}$. The current densities were measured in 20-mL flow of ethanol gas diluted with $\mathrm{He}$ and $\mathrm{N}_{2}$ at the anode and in 20 -mL flow of $\mathrm{H}_{2} \mathrm{O}$-saturated $\mathrm{O}_{2}$ at $75^{\circ} \mathrm{C}$ at the cathode.

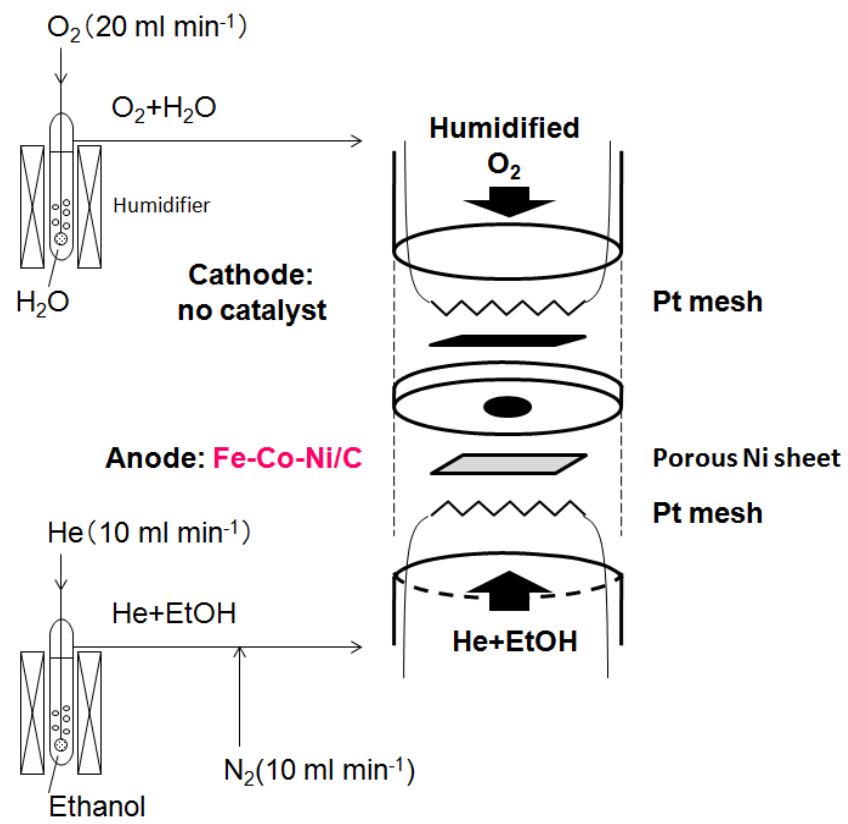

Figure 1 Apparatus for direct-ethanol fuel cell testing 


\section{Results and discussion}

From XRD measurement, formations of the $\mathrm{NaCo}_{2} \mathrm{O}_{4}$ structure and $\mathrm{Fe}-\mathrm{Co}-\mathrm{Ni}$ alloy were confirmed. $\mathrm{OH}^{-}$conductivity of $\mathrm{NaCo}_{2} \mathrm{O}_{4}$ was confirmed by concentration cell and water transfer experiments,

Results of the hydrogen oxidation are shown in Figure 2. Although the cathode is catalyst-free, the open-circuit voltage is as high as $0.8 \mathrm{~V}$ even at room temperature (a). If proton was charge carrier, oxide could not promote oxygen reduction reaction. If anion is charge carrier, oxide can promote oxygen reduction reaction. It is confirmed that the $\mathrm{NaCo}_{2} \mathrm{O}_{4}$ electrolyte, functions not only as an $\mathrm{OH}^{-}$conductor but also as a cathode catalyst.

$$
\begin{aligned}
& \text { Anode } \mathrm{H}_{2}+2 \mathrm{OH}^{-} \quad \rightarrow \quad 2 \mathrm{H}_{2} \mathrm{O}+2 \mathrm{e}^{-} \quad \mathrm{E}^{0}=-0.83 \mathrm{~V} \\
& \text { Cathode } 1 / 2 \mathrm{O}_{2}+\mathrm{H}_{2} \mathrm{O}+2 \mathrm{e}^{-} \quad \rightarrow \quad 2 \mathrm{OH}^{-} \quad \mathrm{E}^{0}=+0.40 \mathrm{~V}
\end{aligned}
$$

When operation temperature increases to $110^{\circ} \mathrm{C}(\mathrm{b})$, current density increases. Both of a catalytic activity and $\mathrm{OH}$ - conductivity increased with temperature. The performance is high enough even at $110^{\circ} \mathrm{C}$, although ordinary $\mathrm{AEM}$ cannot be operated over $70^{\circ} \mathrm{C}$. This property is indispensable for vehicles.

At anode, $\mathrm{Pd}$ activates $\mathrm{H}-\mathrm{H}$ bond, but it is difficult for $\mathrm{Pd}$ to activate $\mathrm{C}-\mathrm{C}$ bond. Since Pd is precious metal, non-precious metal catalyst is desired.

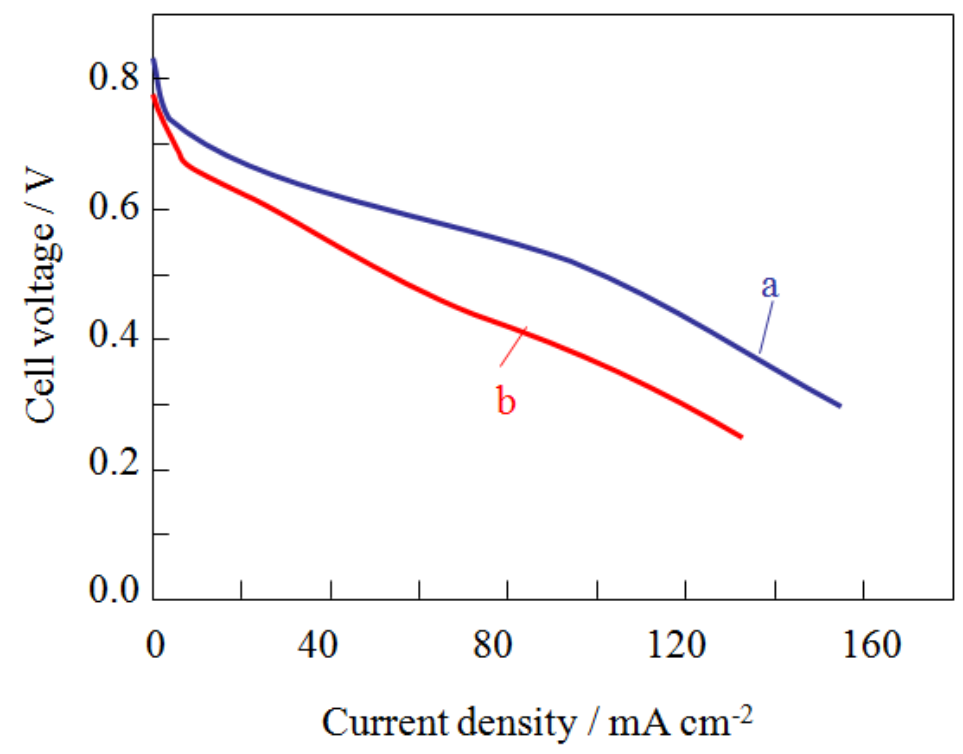

Figure 2 Performance of $\mathrm{Pd} / \mathrm{NaCO}_{2} \mathrm{O}_{4} / \mathrm{NaCo}_{2} \mathrm{O}_{4}$ fuel cell at a) the room temperature and b) $110^{\circ} \mathrm{C}$. 


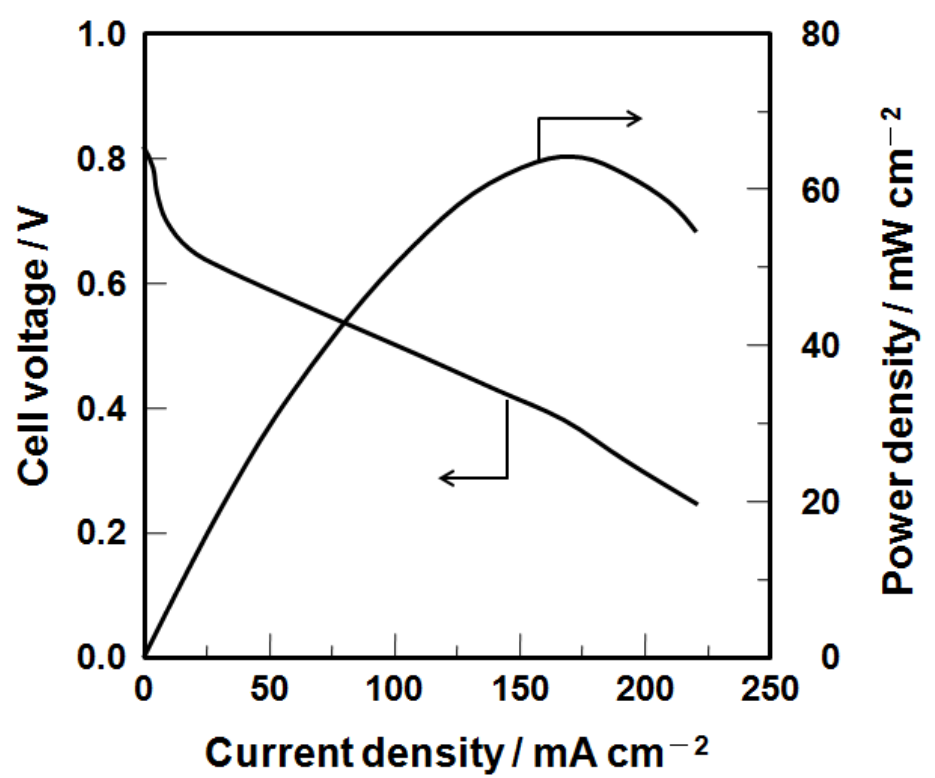

Figure 3 Performance of direct-ethanol solid alkaline inorganic fuel cell testing Anode, $\mathrm{Fe}-\mathrm{Co}-\mathrm{Ni}$; electrolyte: $\mathrm{NaCo}_{2} \mathrm{O}_{4}$; cathode: catalyst free; Cell Temp., $80^{\circ} \mathrm{C}$; Anode gas, $20-\mathrm{mL}$ flow of ethanol/ $/ \mathrm{He}+\mathrm{N}_{2}$; Cathode gas, $20-\mathrm{mL}$ flow of $\mathrm{H}_{2} \mathrm{O}$ -

Figure 3 shows the performance of direct-ethanol solid alkaline inorganic fuel cell. Although the cathode was catalyst-free and anode is precious metal free, the open-circuit voltage is over $0.8 \mathrm{~V}$. The fuel cell composed of $\mathrm{Fe}-\mathrm{Co}-\mathrm{Ni} / \mathrm{NaCo}_{2} \mathrm{O}_{4}$ generated directly from ethanol a high output power density of $64 \mathrm{~mW} / \mathrm{cm}^{2}$ at current density of 160 $\mathrm{mA} / \mathrm{cm}^{2}$. If the reaction proceeds ideally, the following reaction is expected.

$$
\begin{array}{lllll}
\text { Anode } & \mathrm{C}_{2} \mathrm{H}_{5} \mathrm{OH}+12 \mathrm{OH}^{-} & \rightarrow & 2 \mathrm{CO}_{2}+9 \mathrm{H}_{2} \mathrm{O}+12 \mathrm{e}- & \mathrm{E}^{\circ}=-0.743 \mathrm{~V} \\
\text { Cathode } & 3 \mathrm{O}_{2}+6 \mathrm{H}_{2} \mathrm{O}+12 \mathrm{e}^{-} \rightarrow & 12 \mathrm{OH}- & \mathrm{E}^{\circ}=+0.40 \mathrm{~V}
\end{array}
$$

Fe-Co-Ni alloy catalysts have activity for ethanol oxidation reaction. At least, $\mathrm{C}-\mathrm{H}$ bond was activated by the $\mathrm{Fe}-\mathrm{Co}-\mathrm{Ni}$ alloy catalysts. Indeed, formation of $\mathrm{CO}_{2}$ must be confirmed for next study. As relatively high voltage was obtained directly from liquid fuel with high energy density, this technology will be desirable for mobile fuel cell systems.

\section{Conclusions}

Anion-conducting solid alkaline inorganic fuels cell could be operated at high temperature of $110^{\circ} \mathrm{C} . \mathrm{NaCo}_{2} \mathrm{O}_{4}$ showed an activity for oxygen reduction reaction. The Fe-Co-Ni alloy catalyst prepared in this experiment showed activity not only for hydrogen oxidation reaction but also for ethanol oxidation reaction. Completely precious metal-free fuel cell composed of $\mathrm{NaCo}_{2} \mathrm{O}_{4}$ and $\mathrm{Fe}-\mathrm{Co}-\mathrm{Ni}$ cell generated a high output power density directly from ethanol. 


\section{Acknowledgments}

This study was supported by Strategic Development of PEFC Technologies for Practical Application Grant Program from New Energy and Industrial Technology Development Organization (NEDO) of Japan.

\section{References}

1. J. S. Park, S. H. Park, S. D. Yim, Y. G. Yoon, W. Y. Lee and C. S. Kim, J.Power Source, 178, 620 (2008).

2. E. Agel, J. Bouet, and J. F. Fauvarque, J. Power Source, 101, 267 (2001).

3. C. Tamain, S. D. Poynton, R. C. T. Slade, B. Bryony and J. R. Varcoe, J. Phys. Chem. C, 111, 18423 (2007).

4. Department of Energy, USA. Multi-Year Research, Development and Demonstration Plan, 2007 Technical Plan - Fuel Cell, 20 (2007).

5. R. E. Schaak, T. Klimczuk, M. L. Foo, and R. J. Cava, Nature 424, 527 (2003)

6. C. Bianchini, in Small Fuel Cells for Portable Applications, Knowledge Press, 7th edn, 2006, pp. $227-251$. 